\title{
European Perspectives on Export Performance Determinants: \\ An Exploratory Study*
}

\author{
Luis Filipe Lages, \\ Carmen Lages, \\ Cristiana Raquel Lages **
}

2004

* This research was funded by a research grant from the 6th European Framework Program, Specific Support Action-CoCombine. Luis Filipe Lages is grateful to "Nova Égide”. This research has also benefited from the support of Warwick Business School and UMIST (UK) in conducting the surveys. The authors also thank the valuable work of Elisabeth Santos in data coding.

** Luis Filipe Lages is Assistant Professor of Marketing and International Business at Universidade Nova de Lisboa, Faculdade de Economia, Campus de Campolide, 1099-032 Lisboa, Portugal. E-mail: lflages@fe.unl.pt; http://docentes.fe.unl.pt/ lflages; Telephone: +351.213.801.600; Fax: +351.213.886.073.

Carmen Lages is Assistant Professor of Marketing at ISCTE Business School - Lisbon, Av. das Forças Armadas, 1649-026, Lisboa, Portugal. E-mail: carmen.lages@iscte.pt; Telephone: +351217903000 / 217935000 .

Cristiana Raquel Lages is affiliated with Warwick University, Warwick Business School, U.K. E-mail: c.r.c.lages@warwick.ac.uk Telephone: +44.24.7652.2546; Fax: +44.24 .7652 .4650 . 


\title{
European Perspectives on Export Performance Determinants: An Exploratory Study
}

\begin{abstract}
This exploratory study discusses main antecedents of export performance based on the perceptions of European export managers. Cross-national findings reveal that according to managerial perceptions the most important determinants of export performance are product quality, followed in importance by price competitiveness/value for money, service quality and relationship with importers/trust. While some of these determinants have been extensively researched in the literature (product and service quality), there are others in which there is limited empirical research (price competitiveness/value for money and relationship with importers/trust). Also of interest is the existence of specific issues that are not considered by managers as being top determinants, but are the focus of extensive research. Based on these findings the authors suggest several potentially fruitful streams of research.
\end{abstract}

Keywords: Qualitative Study; Export Performance; Export Marketing; Cross-National 


\section{INTRODUCTION}

Research on export performance is nearly four decades old, having been initiated in the pioneering work of Tookey (1964). During these last four decades, world exports have grown exponentially, reaching nearly 20 per cent of the world's gross domestic product (World Bank, 1998). As a consequence of the growing importance of the exporting activity, export marketing has become a priority for both practitioners and academics. A great deal of empirical research has been developed, particularly in recent years, leading to the resurgence and development of seven major research streams in the literature (Katsikeas, Bell, and Morgan, 1998, p. 323). These streams are concerned with (1) the factors that stimulate a firm's decision to initiate exporting or assure the exporting activity; (2) the problems or barriers faced by firms when initiating exporting or maintaining export operations; (3) the elements which influence export development; (4) network relationships and their role in export development and internationalization; (5) the nature, importance and utilization of information acquired for export marketing decision making; (6) the nature and effectiveness of governments' promotion and assistance programs; and, finally, (7) the identification of the factors that influence export performance, with a particular emphasis on the export marketing strategy - export performance relationship. Our focus will be on this last stream of literature. This last stream is a particularly interesting and timely topic, particularly if we consider that firms' survival and growth, and the consequent economic growth of many countries, is strongly dependent on a better understanding of the key factors influencing firms' exporting performance.

Surprisingly, and despite forty years of intense empirical research on the topic, several articles (e.g., Madsen,1998; Lages and Montgomery, 2002; Lages and Jap,, 2003) argue that export performance is often not aligned with managers' views and interests. A possible reason might be the small number of qualitative studies and, in particular, the inexistence of open-ended questions that limit bias from respondents to a minimum. With this in mind, we use an open-ended question to identify which factors are perceived by exporting managers as being the most influential to the performance of export market ventures (i.e., a selected exported product or group of products to an importer in a single country). Hence, although partially driven by the literature, this study is mainly inductive. The main objective is to gather cross-national exploratory data about the exporting dynamics. This approach is similar to that used in grounded theory methodology, in which, through a set of procedures, it is 
possible to develop grounded theory about what is observed in the field (Glaser and Strauss, 1967; Strauss and Corbin, 1990). This approach is more appropriate when the investigator intends to answer 'what/which' and 'how' questions (Yin, 1994), such as 'which factors contribute to export performance' and 'how do companies achieve export performance?'

Both the Marketing Science Institute and Journal of Marketing Research (MSI/JMR, 2003) recently declared that there is an increasing concern about the divergence between the research conducted by marketing academics and managers' reality. With this open-ended approach we expect to contribute toward bridging the gap between academics and practitioners. It is expected to reflect and be derived from business practice in order to influence future export marketing research. It is our objective to identify top determinants of export performance as identified by export managers of different countries. We are particularly interested in identifying which top determinants are common across two different research settings. Moreover, it is our aim to learn if the identified top determinants are aligned with those discussed throughout these four decades by the export marketing literature.

In the pages to follow we start by presenting the theoretical background supporting this research study. We then test our research question via a field survey of Portuguese and British exporting managers. Results are presented and then discussed. Implications for theory and managerial practice, limitations of the research, and future directions are also considered.

\section{THEORETICAL BACKGROUND}

\section{Export Performance}

In this study we rely on the manager's perception of the performance of a single export venture (i.e., a single product or product line exported to a single foreign market). It is believed that analyzing a single product or product line exported to a single foreign market makes it possible to associate past performance more precisely with its antecedents (Cavusgil and Zou, 1994). Moreover, as the unit of analysis is a specific export venture, responding executives have detailed knowledge of its performance and determinants. Performance is an indispensable guide for any company analyzing its level of success, in both the domestic and international arenas. In the export marketing literature researchers have used many different ways to assess export performance, as no consensus exists about its conceptual and operational definitions. This might explain why the task of dealing with performance is so complex. Indeed, as Bonoma and Clark (1988: 1) commented, “perhaps no other concept in 
marketing's short history has proven as stubbornly resistant to conceptualization, definition, or application”. There are several factors supporting the use of a subjective approach to performance assessment. Although objective assessment of actual performance may be regarded as trustworthy, this type of approach may raise different problems (see: Venkatraman and Ramanujam, 1986). As indicated by Styles (1998), since samples are often drawn from a heterogeneous population of exporting firms, the researcher --rather than managers-- usually is the one who fixes the performance levels. A second problem is that financial approaches (e.g., profitability, ROI, cash-flow) might raise comparison problems due to different accounting practices across firms. A third practical concern is that obtaining accurate financial data on export performance is a difficulty acknowledged by researchers, because export managers might be unwilling to respond openly and effectively to absolute values (Katsikeas, Piercy, and Ionnidis, 1996; Yang, Leone, and Alden, 1992). Finally, both stakeholders and managers may have different opinions about which operational measures to use when setting targets. For this reason it becomes very difficult to find agreement on how to use financial measures to assess export performance (Madsen, 1998). Moreover, the existing differences in terms of characteristics of the market, level of competition and technology intensity might lead to a comparison of financial measures with different meanings across the various firms (Katsikeas, Piercy, and Ionnidis, 1996). That is why managers tend to use their own perceptions of performance, rather than objective values, in order to formulate their own decisions (Bourgeois, 1980).

In sum, all these reasons might explain why subjective approaches have been proven to be more valid in assessing export performance and in determining the manner in which performance is associated with managerial decisions (see: Katsikeas, Leonidou, and Morgan, 2000: 505). By asking managers to identify determinants of their own perceived performance, instead of determinants of performance per se, we are able to capture the “performance benchmark" that managers use for decision-making (Lages and Jap, 2003). In this way we expect to better match our research question with managers' reality.

\section{Determinants of Export Performance}

Over the last four decades, the contingency perspective has been advocated by many theorists and discussed at several levels (Galbraith and Schendel, 1983). The most recent literature on the determinants of export performance, particularly after Cavusgil and Zou's (1994) contribution, is also based on this approach. The contingency perspective has been well accepted in organizational studies (McKee, Varadarajan, and Pride, 1989) and marketing 
research (Zeithaml, Varadarajan, and Zeithaml, 1988). Its defenders argue that this perspective provides the right way to deal with export performance determinants. While building on the contingency theory, many studies have attempted to identify key factors that contribute to exporting performance. Indeed, notable meta-analyses have been done in recent years to systematize all the extensive literature on this topic (see: Leonidou, Katsikeas, and Samiee, 2002; Zou and Stan, 1998). Despite the exploratory nature of this study, this paper will build on the most recent meta-analysis on the topic (Leonidou, Katsikeas, and Samiee, 2002) to systematize and compare our inductive findings with previous export marketing literature.

\section{METHOD}

\section{Research Setting}

The research setting is two developed member countries of the EU (Portugal and the U.K.). Research within this arena is particularly pertinent as the EU is the world's largest exporter of goods, maintaining a stable share of approximately one fifth of total world exports (intraEU trade excluded) since 1990 (European Commission, 2000). Moreover, both Portuguese and British economic growth depends heavily on the exporting success of national firms and for both countries the majority of trade is done with other EU countries.

\section{The Unit of Analysis}

The unit of analysis employed in this research is a single export venture, i.e., a single product or product line exported to a single foreign market. The use of an export venture is in line with a large number of previous empirical studies (e.g. Bilkey, 1982; Madsen, 1989; Cavusgil and Kirpalani, 1993; Cavusgil and Zou, 1994). This approach will allow future researchers using our findings to associate export performance more precisely with its antecedents. This unit of analysis is chosen because if a firm's overall performance is analyzed as a whole, it is extremely difficult to isolate the effects of specific actions (Cavusgil and Kirpalani, 1993). If more than one export venture from the same firm were used, this would increase the likelihood of bias.

Similarly to previous research (e.g. Cavusgil and Zou, 1994; Styles, 1998), in order to classify the selected export venture, both Portuguese and British managers were initially asked to indicate a single exported product, or group of exported products, as well as a single foreign importer for that(those) product(s). These questions were then followed by an openended question in which managers were asked to indicate what the main reason was 
influencing the selected exporting venture's performance. For the survey conducted in Portugal, questions were initially developed in English and then translated into Portuguese. In order to avoid translation errors, questions were back-translated into English by a different researcher.

\section{Data Collection Procedure}

\section{Portugal}

A sample of 2,500 firms was randomly generated from a governmental agency database of ICEP-Portugal (1997). This database of 4,765 Portuguese exporters was the most comprehensive and up-to-date database available in the Portuguese market at the time of data collection (1999). The pretest results indicated a strong need for an incentive to motivate the respondents to participate. In the cover letter it was stated that in return for a completed survey respondents would be provided with a report of the final results, and a list of contacts for potential overseas importers or clients. ${ }^{1}$ Additionally, confidentiality was assured.

In the first mailing, a cover letter, a questionnaire, and an international postage-paid business reply envelope were sent to the person responsible for exporting in each of the 2,500 Portuguese firms. This missive was followed by a second mailing that included a reminder letter and a postage paid reply envelope. Out of the sample of 2,500 Portuguese managers, 29 stated that they no longer exported and 119 questionnaires were returned by the postal service. These firms had either closed down or moved without leaving a forwarding address. Thus, the sample size was reduced to 2,352. Of the 593 returned questionnaires, 81\% (478) of the managers answered the open-ended question that is the focus of this paper.

\section{United Kingdom}

A sample of 1,564 British enterprises was randomly generated from a database of the British Chamber of Commerce denominated "British Exports 2000" (2000). An incentive was stated in the cover letter: in return for a completed questionnaire, the findings would be available after the completion of the study. Confidentiality was also assured. The data collection was conducted in 2002. As with the Portuguese survey, a cover letter, questionnaire, and postagepaid business reply envelope were sent to the person responsible for exporting in each of the British firms of the sample. Unfortunately, unlike the case in the Portuguese survey, governmental funding was not obtained to conduct the research. Consequently, due to the lack of financial resources, a reminder mailing was not sent. 
Similarly to Menon et al.'s (1999) method, we contacted 100 randomly chosen respondents to determine undeliverable and noncompliance rates. We determined that $34 \%$ of the mailings were undeliverable because of incorrect address; an additional 40\% did not reach the person responsible for the export operations in the firm due to company gatekeepers; and $4 \%$ of the respondents reported a corporate policy of not responding to academic surveys. Thus, the sample size was reduced to 344. Of the 111 returned questionnaires, 97\% (108) of the managers have answered the open-ended question, which is the focus of this paper.

\section{Coding Procedure}

The coding procedure followed six steps. First, all answers to the open-ended question were entered ipsis verbis into a Word Processor. When more than one word or expression were proposed by respondents as the main determinant of the selected export venture's performance, all were considered as having equal weights because no preference ranking could be inferred.

Second, all answers were coded independently by two researchers (one marketing professor and one research assistant) and verified by one independent judge (marketing professor). Overall, no significant differences of meaning were identified; and when disagreements arose, the independent expert judge, together with the two researchers, determined the final coding. Ultimately, the best way to protect against interpretive bias is to be constantly aware that the respondent's perspective should guide final interpretation.

Third, an interactive process of open coding of data with constant comparative analysis was used. Analysis of the open-ended answers relied on the meaning-based abstraction and conceptual labeling. With the reading of each new answer, the analytic strategy shifted gradually from open coding of data to comparison of new data elements with previously coded incidents that shared similar conceptual properties. Coding of subsequent data was based on themes and patterns that emerged across answers. Qualitative researchers describe this interactive process as back-and-forth analysis in which new data are compared to concepts in use and new concepts are compared to previously coded data in a constant comparative analysis.

Fourth, this interactive process leads to a list of keywords. Keywords are defined as manifest indicators of similar critical meanings. Fifth, as a consequence of a discussion between the

\footnotetext{
${ }^{1}$ This list is generated using on-line information, mainly information available on websites of several Chambers of Commerce, where a list of importers is normally listed by sector.
} 
two researchers, many of the keywords were collapsed, renamed, and reorganized in light of the research question, evolving into the format laid out in a final list (see Table 1). Saturation was achieved when each bit of relevant data had been successfully grouped into one thematic category, and when the leftover data were determined to be irrelevant to the research questions at hand.

Insert Table 1 about here

The final step consisted in the application of a pre-determined category system to our categories in order to interpret keywords according to an existing interpretational schema. This step was based on Leonidou, Katsikeas and Samiee’s (2002) meta-analysis. Their work identifies five major groups of variables that influence export performance: (1) managerial, (2) organizational, (3) environmental, (4) export targeting, and (5) marketing mix variables. The authors conceptualize "managerial” as referring to variables related to characteristics of exporting firms’ decision-makers; “organizational” relates to characteristics of the exporting firm; "environmental" regards macro influences on the exporting activity; "targeting" concerns segmentation and targeting of (international) markets; and "marketing mix variables” relate to export strategy at the product, price, distribution and promotion levels. These groups of variables were divided in two, the first being comprised of managerial, organizational and environmental as antecedent forces indirectly affecting export performance; and the second comprised of targeting and marketing mix variables as elements of the export marketing strategy that directly affect export performance (Leonidou, Katsikeas and Samiee, 2002, p. 52).

\section{Data Analysis}

The data obtained for the previous open-ended question for British and Portuguese exporters are now analyzed. The analysis of the Portuguese and the British data is done separately because: 1) data collection occurred in two different years, and 2) there is a high possibility that managerial perceptions of performance and its determinants might be different in the two countries.

Out of 478 valid Portuguese answers (i.e., reasons for exporting ventures’ performance), 866 keywords emerged (an average of 1.8 keywords per respondent). Each answer was analyzed by two researchers. The final codification led to 43 marketing categories. Out of 108 usable 
British questionnaires, 167 keywords (an average of 1.5 keywords per respondent). The final codification led to 39 marketing categories.

All sizes of firm are represented in the samples. Both Portuguese and British exporting industries are primarily composed of SMEs. Of the exporting firms represented in the samples, $5 \%$ of the Portuguese firms and $6 \%$ of the British companies have more than 500 employees, and hence are considered SMEs. With regard to the Portuguese sample, the average annual export sales of these firms ranged from USD $\$ 350,000$ to $\$ 1.5 \mathrm{M}$. In the British sample, the average annual export sales of these firms ranged from USD \$470,000 to $\$ 1.6 \mathrm{M}$.

Both surveys were sent to individuals who were primarily responsible for exporting operations and activities. The job title of these individuals included president, marketing director, managing director, and exporting director. Respondents in both countries were asked to indicate their degree of experience in exporting on a scale where $1=$ none and 5=substantial. The mean response for Portugal was 3.6 ( $\mathrm{sd}=.84$, range 1 to 5 ) and for the U.K. was 3.8 ( $\mathrm{sd}=.93$, range 1 to 5 ). Collectively, this indicates that although the title of the respondents' positions may be wide-ranging, the individuals were experienced with exporting in general and appear to have considerable knowledge in the specific exporting activities of the firm.

\section{FINDINGS}

Exporters' perceptions of the main determinants of their exporting venture's performance are very similar for both Portuguese and British samples. Findings across both samples reveal that the most important determinant of export performance is product quality, followed in importance by price competitiveness/value for money, service quality and relationship with importers/trust. Other determinants of export performance identified across the two European countries' samples are: degree of competition, design, brand image, distribution network/availability, product differentiation, innovation, strategy adaptation, promotion, and foreign market characteristics (dimension/potential). Based on Leonidou, Katsikeas and Samiee's (2002) pre-determined five category system, we have assigned the different determinants to each one of the five categories (see Table 1- categories are in brackets). As one observes in Table 1, the Top 4 across both samples are included in the "marketing mix" group of variables. This suggests that exporters spontaneously perceive marketing strategy as being central to export performance. The other four groups - i.e. environmental, targeting, managerial and organizational variables (Leonidou, Katsikeas and Samiee, 2002) - are much 
less-cited across both samples as being critical factors of export performance. The only exception is a variable included in the environmental group of variables, competition, which was considered as a vital external force for exporting firms of both countries. A possible explanation is that managers perceive that in competitive environments market shares become more volatile (Day and Wensley, 1988) and intense competition increases market uncertainty and unpredictability (Gupta, Raj and Wilemon, 1986).

\section{DISCUSSION OF MAIN FINDINGS}

With regard to product issues specifically, our findings suggest that managerial concern is aligned with researchers' interests. Previous research has extensively researched product quality as a determinant of export performance (Leonidou, Katsikeas and Samiee, 2002). Our findings also reveal that the most-cited determinant of export performance across both samples is product quality. Service quality was identified as another top concern. This is also in line with the literature, which considers (pre- and after-sales) service quality as a critical success factor in international marketing (Terpstra and Sarathy, 1997).

Surprisingly, with regard to price competitiveness/value for money our managerial findings are not aligned with the literature. Price competitiveness/value for money is presented by Portuguese and British managers as being the $2^{\text {nd }}$ most-important issue. Despite managerial awareness of pricing importance to export performance, this is a topic that has received limited research attention (Myers and Cavusgil, 1996; Rosenbloom, Larsen, and Mehta, 1997). The reasons for neglecting pricing strategies and practices at the international level can be attributed to the complexity of pricing issues, as well as to the reluctance of managers to discuss their pricing strategies (Myers and Cavusgil, 1996). Similarly, both Portuguese and British export managers perceive that the relationship with importers/trust must be seen as a main concern. Managers perceive that trust promotes positive joint results and prevents problems in exporting relationships. This is another area in which much more export marketing research is required when analyzing both sides of the dyad involved in exporting relationships. Although there is a growing body of research looking into the behavioral aspects of the relationship between buying and selling organizations in export markets (Leonidou and Kaleka, 1998; Rosson and Ford, 1982; Styles and Ambler, 1994), a better understanding of how to develop sound relationships is critical to successful export activity. Finally, promotion is not seen by Portuguese and British exporters as being a top issue. This is even more surprising when considering that export promotion is one of most-discussed topics in the export-marketing field (Zou and Stan, 1998). 


\section{DISCUSSION OF DISSIMILARITIES ACROSS BOTH SAMPLES}

This empirical study identifies Portuguese and British managers' perceptions on export performance antecedents. With this research it is expected to capture practical knowledge within a theoretical framework. It is believed that these combined perspectives of theory and practice focus our research agenda.

Despite the qualitative exploratory nature of this study, findings reveal that the great majority of keywords (i.e. 13 out of 22) are identical across both samples. Nevertheless, some dissimilarities were also found across the Portuguese and British samples. The most interesting divergence is that while delivery deadlines is a key aspect to Portuguese exporters ( $3^{\text {rd }}$ top keyword), this aspect was not revealed as being a key issue for British exporters. This finding might imply that in contrast to what occurs with British exporters, delivery time is not a "taken for granted" situation for Portuguese exporters. Additional research is required to better understand this issue. Already in the early 1980s, Cavusgil and Nevin (1981) noted that research dealing with distribution decisions was very limited. Over two decades later, research on international distribution remains so (Rosenbloom, Larsen, and Mehta, 1997). The existing research indicates that the relationship between specific export distribution modes and individual performance measures is inconclusive (Leonidou, Katsikeas, and Samiee, 2002). This might also explain why this distribution issue (delivery deadlines) was not found to be simultaneously important for both samples.

Although it is not our aim to explain the impact of the different characteristics of the two research settings on the different results across the two samples $\equiv$ are mostly concerned with the identification of export performance determinants that are common across different settings), some possible explanations for the existing dissimilarities may be presented. A possible explanation might be associated with answer inequivalence arising from language differences between Portuguese and British managers. Nevertheless, this situation was minimized by the relative straightforward nature of the questions (Styles, 1998). Another possible reason is associated with the interpretation of the contextual variables (Craig and Douglas, 2000). Naturally, as a consequence of different personal and country realities, when Portuguese and British respondents were evaluating the determinants of the selected export venture performance, they might have used different contextual backgrounds as a basis. Finally, Styles (1998) suggests that different levels of familiarity and experience with export operations might be another problem. However, as previously discussed, this does not seem 
to be a concern in this study, because an analysis of sample means revealed that the individuals were experienced and knowledgeable in exporting.

In sum, despite some evident limitations associated with the fact of different countries presenting different characteristics (in terms of culture, values, language, educational levels, etc), it is believed that the use of cross-national exploratory findings is useful in identifying which determinants are stable across different research settings (even when these settings present major differences). Nevertheless, due to the high exploratory and qualitative nature of our findings, we recommend that our results should be regarded as suggestive rather than conclusive. Particular attention should be given to the 13 determinants that were identified as being common across both samples.

\section{CONCLUSION AND RESEARCH DIRECTIONS}

Executives are voicing concerns about the relevance of academic research from a practitioner point of view. This issue depends on several factors, and it will be hard to solve all the underlying concerns. For example, both the reward systems and goals of practitioners and academics are clearly different. Moreover, managers often lack methodological resources to resolve key industry problems and academics, although often having tools that can provide relevant insights, lack the motivation or data needed to address those problems (MSI/JMR, 2003). It is our goal with this cross-national study to contribute toward stimulating future interaction between export marketing practitioners and academics in ways that result in new insights into the export marketing literature and practice. Despite the qualitative and inductive nature of this study, our cross-national validation indicates that many determinants are identical across both samples and, hence, are suggested to be integrated into future export marketing research. While some of these determinants have been extensively researched in the literature (e.g. product and service quality), there are others in which there is limited empirical research (e.g. price competitiveness/value for money and relationship with importers/trust). Also interesting is the existence of specific export marketing areas in which there is extensive research (e.g. promotional strategy), which were not considered by managers across both samples as being top priorities.

Findings reveal that product quality leads managers' perceptions in both samples. Several studies have already demonstrated that having a market orientation, rather than a product orientation, may improve performance (Day and Wensley, 1988; Jaworski and Kohli, 1993; Kohli and Jaworski, 1990; Lusch and Laczniak, 1987; Narver and Slater, 1990). Although product quality might be perceived by managers as a key factor, it is believed that firms 
should take into consideration all the factors of a marketing strategy, and not be exclusively product-driven (see: Douglas and Wind, 1987). Exporting firms that are product oriented are more vulnerable to attacks from overseas competition (Cavusgil and Zou, 1994). Managers are recommended to implement a well-designed export marketing strategy, since the overwhelming majority of the marketing strategy variables tend to be significantly associated with export performance. Within this line, a further interesting possibility for future research is to develop and create international business frameworks, which examine the marketing mix as a whole, rather than concentrating on just one of the "Ps". Due to the complexity of the export-marketing phenomenon, frameworks are important both at the conceptual and empirical levels, and wherever possible should use grounded findings.

Future research should also identify key drivers of export performance by investigating importers' perceptions on this topic (see: Skarmeas, Katsikeas, and Schlegelmilch, 2002). Such an approach would bring interesting guidelines for improving the exporter-importer relationship as well as firms’ export performance.

Future empirical studies might try to test for the contexts in which the impact of the determinants presented here might be positive, negative or non-significant, by testing, for example, the moderating effects of product/industry type (e.g. a service industry and a goods manufacturing industry), firm's size (e.g., SME and large firms), and firm's exporting experience (e.g. start-ups and established exporters). Finally, research is also encouraged, not only on export performance antecedents, but also on export performance outcomes. It is believed that past export performance levels have an impact at the firm level (see: Lages and Montgomery, 2002; Lages and Jap, 2003). This is something overlooked by previous empirical research.

To conclude, and given the importance of the issues discussed in this paper for export managers and researchers, it is hoped that this investigation will contribute toward reducing the gap between research and practice as well as stimulate future research in the exportmarketing field to include export performance determinants of managerial relevance. 
Table 1 - Top Determinants of Export Performance

\begin{tabular}{|c|c|c|c|c|c|}
\hline \multicolumn{3}{|c|}{ Portuguese Exporters } & \multicolumn{3}{|c|}{ British Exporters } \\
\hline Top & Determinants & $\begin{array}{c}\% \\
\text { (\# mentions } \\
\text { out of } 866 \text { ) }\end{array}$ & Top & Determinants & $\begin{array}{c}\% \\
\text { (\# mentions } \\
\text { out of 167) }\end{array}$ \\
\hline 1. & Product quality (5) & $30.6 \%(265)$ & 1. & Product quality (5) & $22.2 \%(37)$ \\
\hline 2. & $\begin{array}{l}\text { Price competitiveness/value } \\
\text { for money (5) }\end{array}$ & $22.2 \%(192)$ & 2. & $\begin{array}{l}\text { Price competitiveness/value } \\
\text { for money (5) }\end{array}$ & $10.8 \%(18)$ \\
\hline 3. & Delivery deadlines (5) & $8.1 \%(70)$ & \multirow[t]{2}{*}{3.} & Service quality (5) & $9.0 \%(15)$ \\
\hline 4. & Service quality (5) & $6.0 \%(52)$ & & $\begin{array}{l}\text { Relationship with } \\
\text { importers/trust (5) }\end{array}$ & $9.0 \%(15)$ \\
\hline 5. & Competition degree (3) & $4.4 \%(38)$ & 5. & Brand image (5) & $6.6 \%(11)$ \\
\hline 6. & $\begin{array}{l}\text { Flexibility/response capability } \\
\text { (2) }\end{array}$ & $3.5 \%(30)$ & 6. & Technical ability (1) & $6.0 \%(10)$ \\
\hline 7. & Design (5) & $3.0 \%(26)$ & \multirow[t]{3}{*}{7.} & Competition degree (3) & $4.8 \%(8)$ \\
\hline 8. & $\begin{array}{l}\text { Relationship with } \\
\text { importers/trust (5) }\end{array}$ & $2.9 \%(25)$ & & $\begin{array}{l}\text { Distribution network/ } \\
\text { availability (5) }\end{array}$ & $4.8 \%(8)$ \\
\hline 9. & Brand image (5) & $2.1 \%(18)$ & & Product differentiation (5) & $4.8 \%(8)$ \\
\hline 10. & $\begin{array}{l}\text { Distribution network/ } \\
\text { availability (5) }\end{array}$ & $1.8 \%(16)$ & 10. & Design (5) & $3.6 \%(6)$ \\
\hline \multirow[t]{3}{*}{11.} & Innovation (5) & $1.7 \%(15)$ & 11. & Promotion (5) & $2.3 \%(4)$ \\
\hline & Strategy adaptation (5) & $1.7 \%(15)$ & \multirow[t]{4}{*}{12.} & Innovation (5) & $1.8 \%(3)$ \\
\hline & Macro factors/demand (3) & $1.7 \%(15)$ & & $\begin{array}{l}\text { Foreign market } \\
\text { characteristics } \\
\text { (dimension/potential) (4) }\end{array}$ & $1.8 \%(3)$ \\
\hline \multirow[t]{3}{*}{14.} & Promotion (5) & $1.3 \%(11)$ & & Reliability (5) & $1.8 \%(3)$ \\
\hline & Product differentiation (5) & $1.3 \%(11)$ & & Exchange rate (3) & $1.8 \%(3)$ \\
\hline & Experience (1) & $1.3 \%(11)$ & \multirow[t]{3}{*}{16.} & Strategy adaptation (5) & $1.2 \%(2)$ \\
\hline \multirow[t]{2}{*}{17.} & $\begin{array}{l}\text { Foreign market } \\
\text { characteristics } \\
\text { (dimension/potential) (4) }\end{array}$ & $1.0 \%(9)$ & & Commitment (1) & $1.2 \%(2)$ \\
\hline & Market knowledge (1) & $1.0 \%(9)$ & & & \\
\hline
\end{tabular}

Notes:

1. Top determinants in bold are common to both samples.

2. Major groups of variables influencing export performance: (1) managerial, (2) organizational, (3) environmental, (4) export targeting, and (5) marketing mix.

3. Although our objective is not to obtain statistical generalization, it is believed that presenting percentages values facilitates cross-national comparison.

4. Cut-off point for analysis is $1 \%$ (Portugal: at least 9 respondents; UK at least 2 respondents). 


\section{REFERENCES}

Bilkey, W. J. (1982), “Variables associated with export profitability,” Journal of International Business Studies, Vol.13 No. 2, pp. 39-55.

Bonoma, T. V., and Clark, B. H. (1988), Marketing Performance Assessment, Harvard Business School, Boston, Massachusettes.

Bourgeois III, L. J. (1980), "Performance and consensus," Strategic Management Journal, Vol.1 No. 3, pp. 227-248.

British Exports 2000 (2000), Reed Business Information. Windsor: Kompass Publishers.

Cavusgil, S. T., and Kirpalani, V. H. (1993), "Introducing products into export markets: success factors,” Journal of Business Research, Vol. 27 No. 1, 1-14.

Cavusgil, S. T., and Nevin, J. R. (1981), "Internal determinants of export marketing behavior: an empirical investigation,” Journal of Marketing Research, Vol.18 No. 1, pp.114119.

Cavusgil, S. T., and Zou, S. (1994), "Marketing strategy-performance relationship: an investigation of the empirical link in export market ventures," Journal of Marketing, Vol. 58 No. 1, 1-21.

Craig, C. S., and Douglas, S. P. (2000), International Marketing Research. Chichester, England: John Wiley and Sons, Ltd.

Day, G. S., and Wensley, R. (1988), “Assessing advantage: a framework for diagnosing competitive superiority,” Journal of Marketing, Vol. 52 No. 2, pp. 1-20.

Douglas, S. P., and Wind Y. (1987), "The myth of globalization," Columbia Journal of World Business, Vol. 22 No. 4, pp.19-29.

European Commission (2000), DGI Report in http://europa.eu.int/comm/trade/index_en.htm.

Galbraith, C. S. and Schendel, D. (1983), “An empirical analysis of strategy types,” Strategic Management Journal, Vol. 4 No. 2, pp.153 -173.

Glaser, B. G. and Strauss, A. L. (1967), The Discover of Grounded Theory: Strategies for Qualitative Research, New York: Aldine.

Gupta, A. K., Raj, S. P. and Wilemon, D. (1986), “A model for studying R\&D - marketing interface in the product innovation process”, Journal of Marketing, Vol. 50 No. 2, pp.7-17.

ICEP (1997), CD-Export Database: Disk 1. European Union: Dataware Technologies.

Jain, S. C. (1989), "Standardization of international marketing strategy: some research hypotheses,” Journal of Marketing, Vol. 53 No. 1, pp. 70-79.

Jaworski, B., and Kohli, A. K. (1993), "Market orientation: antecedents and consequences," Journal of Marketing, Vol. 57 No. 3, pp. 53-70.

Katsikeas, C. S., Bell, J., and Morgan, R. M. (1998), "Editorial: advances in export marketing theory and practice,” International Marketing Review, Vol. 15 No. 5, pp. 322-332.

Katsikeas, C. S., Leonidou, L. C., and Morgan, N. A. (2000), "Firm-level export performance assessment: review, evaluation, and development," Journal of the Academy of Marketing Science, Vol. 28 No. 4, pp. 493-511.

Katsikeas, C.S., Piercy, N.F. and Ioannidis, C. (1996), "Determinants of export performance in a European context,” European Journal of Marketing, Vol. 30 No. 6, pp. 6-37.

Kohli, A. K., and Jaworski, B. (1990), "Market orientation: the construct, research propositions, and managerial implications,” Journal of Marketing, Vol.54 No. 2, pp. $1-18$.

Lages, L. F. and Jap, S. D. (2003), “The relationship among past performance, marketing mix adaptation, and current export performance improvement in global marketing relationships," Proceedings of the MSI/IJRM Competition, Conference on Global 
Marketing, Marketing Science Institute, Noordwijk, Netherlands.

Lages, L. F., and Montgomery, D. B. (2002), "Rethinking the determinants of export marketing strategy: empirical evidence from SMEs,” In Lorraine Eden Geographies and International Business, Proceedings of the 44th AIB Conference, Academy of International Business, Puerto Rico, USA.

Leonidou, L. C. and Kaleka, A. A. (1998), "Behavioral aspects of international buyer-seller relationships: their association with export involvement," International Marketing Review, Vol. 15 No. 5, pp. 373-97.

Leonidou, L. C., Katsikeas, C. S., and Samiee, S. (2002), "Marketing strategy determinants of export performance: a meta-analysis,” Journal of Business Research, Vol. 55 No. 1, pp. 51-67.

Lusch, R. F., and Laczniak, G. R. (1987), "The evolving marketing concept, competitive intensity and organizational performance," Journal of the Academy of Marketing Science, Vol. 15 No. 3, pp. 1-11.

Madsen, T. K. (1989), "Successful export marketing management: some empirical evidence,” International Marketing Review, Vol. 6 No. 4, pp. 41-57.

Madsen, T. K. (1998), “Executive insights: managerial judgment of export performance," Journal of International Marketing, Vol. 6 No. 3, pp. 82-93.

McKee, D. O., Varadarajan, P. R. and Pride, W. M. (1989), "Strategic adaptability and firm performance: a market contingency perspective,” Journal of Marketing, Vol. 53 No. 3, pp. 21-35.

Menon, A., Bharadwaj, S. G., and Howell, R. (1996), "The quality and effectiveness of marketing strategy: effects of functional and dysfunctional conflict in intraorganizational relationships," Journal of the Academy of Marketing Science, Vol. 24 No. 4, pp. 299-313.

Menon, A., Bharadwaj, S. G., Adidam, P. T., and Edison, S. W. (1999), “Antecedents and consequences of marketing strategy making: a model and a test," Journal of Marketing, Vol. 63 No. 2, pp. 18-40.

MSI/JMR (2003), “MSI \& JMR Competition on practitioner-academic collaborative research”, accessed at 11/11/03 [available at www.marketingpower.com/pubs/jmr/]

Myers, M. B., and Cavusgil, S. T. (1996), "Export pricing strategy-performance relationship: a conceptual framework," in Advances in International Marketing, S.T. Cavusgil and T.K. Madsen, ed., Greenwhich, Conn: JAI Press. Vol. 8 pp. 159-178.

Narver, J. C., and Slater, S. F. (1990), "The effect of a market orientation on business profitability,” Journal of Marketing, Vol. 54 No. 4, pp. 20-35.

Rosenbloom, B., Larsen, T., and Mehta, R. (1997), "Global marketing channels and the standardization controversy,” Journal of Global Marketing, Vol. 11 No. 1, pp. 49-64.

Rosson, P.J., and Ford, D.L. (1982), "Manufacturer-overseas distributor relations and export performance,” Journal of International Business Studies, Vol. 13 No. 4, pp. 57-72.

Skarmeas, D., Katsikeas, C. S., and Schlegelmilch, B. B. (2002), "Drivers of commitment and its impact on performance in cross-cultural buyer-seller relationships: the importer's perspective,” Journal of International Business Studies, Vol. 33 No. 4, pp. 757-783.

Strauss, A. and Corbin, J. (1990), Basics of Qualitative Research: Grounded Theory Procedures and Techniques, Sage Publications Ltd, California.

Styles, C. (1998), "Export performance measures in Australia and the United Kingdom," Journal of International Marketing, Vol. 6 No. 3, pp. 12-36.

Styles, C., and Ambler, T. (1994), "Successful export practice: the U.K. experience," International Marketing Review, Vol. 11 No. 6, pp. 23-47. 
Terpstra, V., and Sarathy, R. (1997), International Marketing, The Dryden Press, Forth Worth, TX.

Tookey, D. A. (1964), "Factors associated with success in exporting," The Journal of Management Studies, Vol. 1 No. 1, pp. 48-66.

Venkatraman, N., and Ramanujam, V. (1986), "Measurement of business performance in strategy research: a comparison of approaches," Academy of Management Review, Vol. 1 No. 4, pp. 801-804.

Yang, Y. S., Leone, R. P. and Alden, D. L. (1992), “A market expansion ability approach to identify potential exporters,” Journal of Marketing, Vol. 56 No. 1, pp. 84-96.

Yin, R. K. (1994), Case Study Research- Design and Methods, Second Edition, Sage Publications, London.

Zeithaml, V. A., Varadarajan, P. R., and Zeithaml, C. P. (1988), “The contingency approach: its foundations and relevance theory building and research in marketing," European Journal of Marketing, Vol. 22 No. 6, pp. 37-64.

Zou, S. and Stan, S. (1998), "The determinants of export performance: a review of the empirical literature between 1987 and 1997,” International Marketing Review, Vol. 15 No. 5, pp. 333-56. 